\title{
NILAI-NILAI FILOSOFIS DALAM UPACARA ADAT MONGUBINGO PADA MASYARAKAT SUKU GORONTALO
}

\author{
Moch Zihad Islami ${ }^{1}$, Yulia Rosdiana Putri ${ }^{2}$ \\ ${ }^{1,2}$ Program Studi Ilmu Filsafat, Fakultas Filsafat, Universitas Gadjah Mada, Yogyakarta \\ zihadislami16@gmail.com \\ yuliarosdiana7putri@gmail.com
}

\begin{abstract}
The research is regarding Mongubingo traditional ceremonies in a Gorontalo tribe. Mongubingo is a series of circumcision custom performed on a baby girl of Gorontalo tribe. This tradition persists although being criticized in terms of health, women's empowerment and child protection. The research aims to find out philosophical meanings and values of Mongubingo traditional ceremonies. The research expected to provide a comprehensive understanding of the whole society regarding Mongubingo traditional ceremonies. The method used is a qualitative-descriptive approach through literature review, observation, interview, and documentation. The result of research indicates that Mongubingo tradition is maintained by the Gorontalo society because of their strong understanding of religious values through their philosophy. Philosophical values of Mongubingo traditional ceremonies are as the manifestation of life and character of the girl. The philosophical values are the basis of their goal to control the morality and social-emotional of children in their development to adulthood, being a woman according to the custom, culture, and religion of the Gorontalo tribe.
\end{abstract}

Keywords : Women Circumcision, Philosophical Values, Local Wisdom.

\section{PENDAHULAN}

Masyarakat Indonesia sebagai masyarakat yang majemuk dapat dilihat dari keberadaan berbagai macam suku, yang di dalam setiap suku bangsa terdapat ciri khas yang membedakan antara suatu suku dengan suku lainnya misalnya dalam hal kebudayaan. Suku bangsa merupakan suatu komunitas manusia yang memiliki nama, menguasai suatu tanah air, memiliki mitos-mitos dan sejarah bersama, budaya publik bersama, perekonomian tunggal, dan hak serta kewajiban bersama bagi semua. Suku bangsa yang tersebar di seluruh wilayah Indonesia ini mempengaruhi keragaman budaya bangsa Indonesia. Kemajemukan budaya ini menghantarkan masyarakat Indonesia pada cara-cara yang khas dan berbeda dalam mengatur tatanan sosial dalam kelompok-kelompok masyarakat.
Pembentukan kebudayaan menurut konsep B. Malinowski mempunyai tujuh unsur universal yaitu bahasa, sistem teknologi, sistem mata pencaharian, organisasi sosial, sistem pengetahuan, religi, dan kesenian (Soelaeman, 1992). Dari ketujuh unsur universal tersebut, religi menjadi unsur dengan pengaruh paling dominan dalam masyarakat suku Gorontalo. Sebab kurang lebih 400 tahun lalu, Gorontalo menjadi salah satu pusat penyebaran agama Islam di Indonesia Timur sehingga seiring dengan itu Gorontalo menjadi pusat pendidikan dan perdagangan masyarakat (Sinaga, 2005). Masyarakat suku Gorontalo memegang kuat adat dan agama dengan berpedoman pada falsafah "Adat bersendikan Syara' dan Syara' bersendikan Kitabullah" yang merupakan pijakan bersama seluruh masyarakat Gorontalo yang sekaligus 


\section{7 | JURNAL ILMU BUDAY}

dijadikan sebagai sistem etika yang menentukan baik buruknya tindakan seseorang maupun kelompok dalam tatanan sosial Gorontalo.

Salah satu tradisi di masyarakat suku Gorontalo yang telah dilaksanakan sejak dulu hingga sekarang adalah upacara khitan bagi bayi perempuan yang dinamakan Mongubingo, yang terdiri atas rangkaian lihu lo limo dan mo polihu lo limu. Lihu lo limo adalah suatu niat kepada sang bayi perempuan yang akan dikhitan, sedangkan mo polihu lo limu adalah memandikan lemon kepada sang bayi perempuan untuk disucikan (Sinaga, 2005).

Rangkaian unik dari upacara adat Mongubingo adalah setelah prosesi adat lihu lo limo (khitan), dimana bayi dibawa ke tempat pelaksanaan mo polihu lo limu untuk dimandikan dengan air lemon dalam pangkuan ibunya. Adapun siraman yang pertama dilakukan oleh ibunya, siraman berikutnya dari pemangku adat, dan siraman yang terakhir oleh hulango (bidan kampung). Upacara khitan bagi perempuan sejak bayi ini dimaksudkan sebagai proses pembersihan alat kelamin dari kelenjar yang "haram". Di samping itu, upacara khitan ini juga dimaksudkan sebagai lambang pembuka tabir kebenaran dalam ikatan perjanjian suci yang diikat antara Allah dengan Nabi Ibrahim yang kemudian menjadi pola anutan masyarakat Gorontalo turun-temurun sampai sekarang (Sinaga, 2005).

Para ulama sepakat bahwa khitan wanita ada dalam syariat Islam. Tetapi mereka berbeda pendapat mengenai status hukumnya, apakah wajib, sunnah, ataupun hanya anjuran dan suatu kehormatan. Hal ini dikarenakan dalil-dalil yang menerangkan khitan perempuan sangat sedikit dan tidak tegas, sehingga memberikan pendapat yang berbeda di kalangan ulama (Sulthan, 2017).

Tradisi khitan di Gorontalo telah mendapat perhatian langsung dari instansi HAM dan Perlindungan Anak dan Wanita mengenai larangan khitan perempuan karena dampak kesehatan bahkan dianggap sebagai pelecehan kaum perempuan. Menurut data UNICEF 2013 mengenai penyelenggaran khitan bagi perempuan di Indonesia, Gorontalo ada di posisi teratas mengantongi 83.7 persen, menyusul kemudian Bangka Belitung 83.2 persen, lalu Banten 79.2 persen, Kalimantan Selatan 78.7 persen, selanjutnya Riau 74.4 persen, kemudian Papua Barat 17.8 persen, disusul DI Yogyakarta 10.3 persen, Bali 6 persen, Papua 3.6 persen, dan NTT 2.7 persen. Di Indonesia sendiri sunat perempuan adalah hal yang dianggap wajar. Hal tersebut didukung dengan kentalnya adat, budaya, agama, serta dorongan masyarakat, menjadikan 'pemotongan' alat genital perempuan ini dianggap normal dan masih dilakukan hingga sekarang.

Mengakarnya upacara adat Mongubingo pada masyarakat suku Gorontalo tidak dapat dilepaskan dari nilainilai yang mengemban di dalamnya. Masyarakat Gorontalo memiliki tradisi yang nilai-nilainya dipegang teguh dan dijalankan secara turun-temurun. Nilainilai dapat diwujudkan melalui makna simbolik dan filosofis dalam sebuah tradisi. Nilai filosofis menurut konsep 'nilai' Schwartz (1992) adalah suatu keyakinan mengenai cara berperilaku dan tujuan akhir individu, dan digunakan sebagai prinsip atau standar dalam hidup seseorang atau kelompok berdasarkan tingkat kepentingannya. Sebab itu kemudian konsep nilai filosofis menjadi sangat penting untuk perkembangan dan pelestarian sebuah kebudayaan yang ada di suatu masyarakat yang dipercaya memiliki nilai kebaikan bagi masyarakat.

\section{METODE PENELITIAN Jenis Penelitian}

Penelitian ini berusaha menggali nilai-nilai filosofis yang terkandung dalam upacara adat Mongubingo pada masyarakat suku Gorontalo dengan menggunakan 


\section{8 | JURNAL ILMU BUDAY}

metode penelitian kualitatif-deskriptif. Penelitian kualitatif memiliki arti sebagai prosedur penelitian yang menghasilkan data deskriptif berupa kata-kata tertulis atau lisan dari orang-orang dan perilaku yang diamati (Moleong, 1991).

\section{Lokasi dan Waktu Penelitian}

Penelitian ini dilakukan di Kota Gorontalo dan Kabupaten Gorontalo. Lokasi tersebut dipilih karena sebagian besar suku Gorontalo di lokasi tersebut masih menjalankan dan mempertahankan upacara adat Mongubingo. Peneliti melakukan penelitian lapangan pada masyarakat Gorontalo selama 10 hari, pada tanggal 24 April- 4 Mei 2019.

\section{Teknik Pengumpulan Data}

Pengumpulan data penelitian telah diperoleh melalui proses wawancara yang mendalam, observasi yang partisipatif, dan dokumentas. Proses wawancara mendalam didasarkan pada gagasan menggali lebih mendalam tentang subjek atau informan untuk menghasilkan data yang lebih otentik. Dalam penelitian ini, wawancara mendalam ditujukan kepada pelaku dan otoritas adat, akademisi, dan pemerintah terkait. Observasi partisipatif dilakukan untuk mengetahui beragam perspektif yang ada dan membantu dalam memahami interaksi masyarakat. Data observasi partisipatif terdiri dari catatan lapangan rinci yang dicatat catatan peneliti dalam sebuah buku catatan lapangan. Dokumentasi diperoleh melalui fakta yang tersimpan dalam bentuk surat, catatan harian, arsip foto, hasil rapat, cenderamata, jurnal kegiatan dan sebagainya mengenai upacara adat Mongubingo.

\section{Analisis Data}

Analisa data dalam penelitian ini menggunakan metode perbandingan tetap yaitu suatu analisa data yang secara tetap membandingkan satu datum dengan datum yang lain, dan kemudian secara tetap membandingkan kategori dengan kategori lainnya (Moleong, 1991). Proses analisa data mencakup: 1) Reduksi data, yaitu melakukan identifikasi data yang kemudian memberikan kode pada setiap satuan agar dapat ditelusuri sumber data satuannya. 2) Kategorisasi, yaitu memilahmilah setiap satuan ke dalam bagianbagian yang memiliki kesamaan lalu setiap kategori diberi label. 3) Sintesisasi, yaitu mencari kaitan antara satu kategori dengan kategori lainnya.

\section{Teknik Pengambilan Kesimpulan}

Proses pengambilan kesimpulan dilakukan sebagai kelanjutan dari proses analisa data yang terdiri atas reduksi data, kategorisasi, dan sintesisasi. Metode pengampilan kesimpulan terdiri atas verstehen, interpretasi, dan hermeneutika. Teknik verstehen dilakukan dengan melakukan penghayatan atas hasil analisa yang sudah ada. Kemudian, hasil penghayatan tersebut diintrepetasikan ke dalam beberapa poin-poin utama yang nantinya disusun dalam beberapa kalimat. Pada langkah terakhir, poin-poin tersebut diambil bagian makna- makna tersembunyi yang akan dikombinasikan dalam kalimatkalimat akhir dan tetap pada kesimpulan.

\section{HASIL DAN PEMBAHASAN}

Secara historis, upacara adat Mongubingo tidak dapat dilepaskan dari sejarah islamisasi di Gorontalo. Hassanudin \& Basri Amin (2012) menuliskan bahwa proses islamisasi Gorontalo dimulai ketika tokoh elite politik yaitu Raja Amai dari Kerajaan Gorontalo melakukan pernikahan dengan Putri Owutango dari Kerajaan Palasa. Raja 


\section{9 | JURNAL ILMU BUDAYA}

Amai beserta istrinya dan didampingi 8 raja-raja kecil di bawah vasal Palasa yaitu Tamalate, Lemboo, Sitendeng, Hulangato, Siduan, Sipayo, Songinti dan Bunuyo membimbing masyarakat serta merancang adat istiadat yang berpedoman pada Islam.

Pada tahun 1530 agama Islam secara resmi menjadi agama kerajaan dan mengatur adat istiadat dengan memasukkan pengaruh Islam didalamnya. Di dalam kerajaan mulai ditetapkan tentang pentingnya adat istiadat disesuaikan dengan syariat Islam. Hasil rumusan ini dikenal dengan prinsip "saraa topa-topango to adati" artinya "syarah bertumpu pada adat". Proses Islamisasi di Gorontalo semakin meluas dan terstrukturisasi. Hal ini terbukti setelah diberlakukannya suatu pengembangan prinsip hukum adat yang berbunyi:"Aadati hulahulaa to saraa; saraa hulahulaa to adati" (adat bersendi syara, syara bersendi adat) (Hassanudin \& Basri Amin, 2012).

$$
\text { Upacara adat Mongubingo }
$$

merupakan salah satu peninggalan berlakunya adat menggunakan dasar ajaran Islam di Gorontalo sebagai salah satu upacara rangkaian kehidupan pada masyarakat suku Gorontalo yang berupa serangkaian prosesi adat khitan bagi anak perempuan yang menginjakkan usia 1-3 tahun, terdiri atas prosesi lihu lo limo (prosesi khitan anak perempuan), mo polihu lo limu (mandi lemon), dan mopohuta'a to pinggae (injak piring).

\section{Prosesi Upacara Adat Mongubingo}

Sebagian besar masyarakat Gorontalo menjalankan upacara adat Mongubingo berdasarkan alur sebagai berikut :

1. Prosesi momonto dan lihu lo limo (memberikan tanda suci dan mengkhitan bayi perempuan)

a. Satu hari sebelum pelaksanaan Mongubingo, bidan kampung (hulango) sudah mempersiapkan perlengkapan yang dibutuhkan pada prosesi adat. b. Pagi-pagi hari sebelum diadakan prosesi lihu lo limu (khitan anak perempuan), diadakan mongadi salawati (do'a selamat) yang dilaksanakan oleh imam atau hatibi.

c. Setelah prosesi mongadi salawati, kemudian dilanjutkan dengan menyucikan anak perempuan dengan cara dibasuhkan air wudlu.

d. Kemudian anak dipakaikan pakaian adat Gorontalo dan baya lo bo'ute (ikat kepala) untuk menuju prosesi berikutnya.

e. Prosesi berikutnya adalah momonto (memberi tanda suci pada anak perempuan) dengan memberikan alawahu tulihi (kunyit yang dicampur kapur) di dahi, leher, di bawah tenggorokan, di bahu, dan pada lekukan tangan dan kaki sang anak oleh orang tua sang anak.

f. Prosesi khitan dilakukan di dalam kamar dan dilakukan oleh bidan kampung (hulango) dengan didampingi pihak keluarga. Sang anak didudukkan di atas bantal dengan pangkuan orang tuanya.

g. Prosesi khitan dilakukan menggunakan duunito (pisau bambu), namun sekarang sering menggunakan pisau kecil yang tajam.

h. Ketika proses khitan, hulango menutupi prosesi tersebut dengan aluwungo (kain putih).

i. Selaput tipis yang telah dikeluarkan dari alat vital anak perempuan kemudian dimasukkan ke dalam belahan limututu (jeruk purut). 


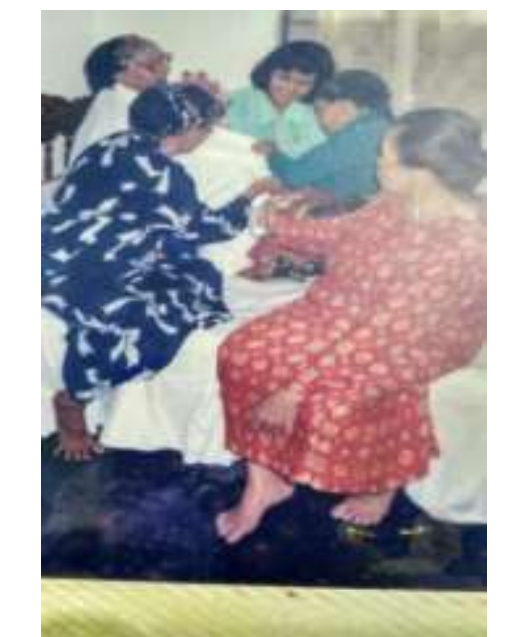

Gambar 1. Prosesi momonto dan lihu lo limo

2. Prosesi mo polihu lo limu (mandi lemon)

a. Sebelum menuju prosesi ini, bayi perempuan yang memakai baju adat dan ikat kepala dilepas (dalam keadaan telanjang).

b. Kemudian ibu dan sang bayi dibawa ke tempat pelaksanaan mo polihu lo limu (mandi lemon) yang telah dihias buah pisang gapi, nanas beserta daunnya, batang tebu, janur kuning, daun puring, dan bulowe (mayang pinang) yang digantung di atas tempat duduk sang ibu dan sang bayi saat dimandikan.

c. Sang bayi dipangku oleh ibunya dan duduk di dudangata (kukuran kelapa) yang menghadap ke timur.

d. Prosesi penyiraman yang dilakukan oleh orang tua sang anak dengan tahulu yilonuwa (air yang diharumkan). Siraman pertama dilakukan oleh ibunya, tetapi dapat diwakili oleh nenek atau tantenya, kemudian siraman kedua oleh ayahnya.

e. Berbeda dengan prosesi siraman yang dilakukan orang tua, siraman berikutnya dilakukan oleh pemangku adat (bate) atau pegawai syara' dengan air perian bambu kuning yang disiramkan melalui bulowe (mayang pinang yang sudah mekar), dilanjutkan siraman terakhir oleh hulango.

f. Prosesi tepuk mayang yang dilakukan dengan menggosokkan bakal buah bulowe (upik pinang) yang baru dibelah pada seluruh anggota badan sang bayi.

g. Prosesi berikutnya adalah memecahkan telur ayam kampung di kukuran kelapa, kemudian diletakkan di kedua tangan anak, sembari itu isi telur yang ada dikedua tangan anak digoyanggoyangkan ke kanan dan kiri dengan bantuan tangan sang ibu selama tiga kali. Setelah itu, kuning telur tersebut ditelankan mentahmentah kepada sang anak.

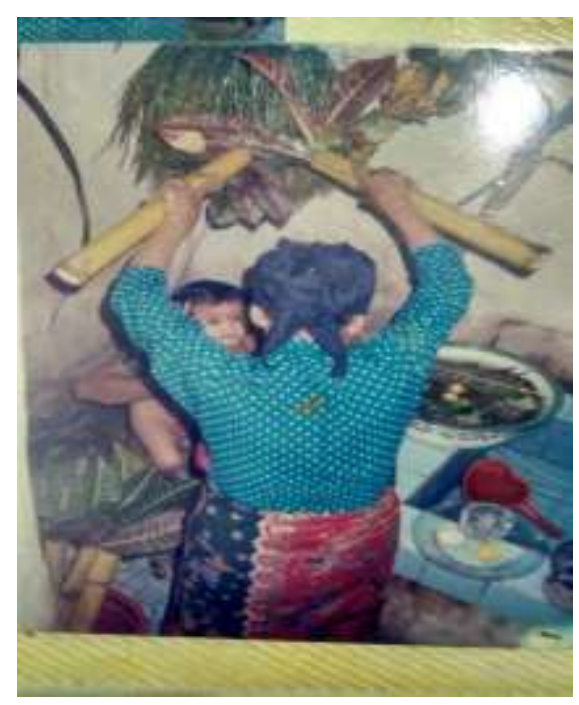

Gambar 2. Prosesi mo polihu lo limu

3. Prosesi mopohuta'a to pinggae (injak piring)

a. Anak yang telah didandani kemudian memasuki ruangan yang telah dihias untuk prosesi mopohuta'a to pinggae.

b. Adapun tujuh buah piring untuk prosesi diisi dengan macam-macam benda yakni tanah dan tanaman rumput, jagung, padi, uang koin, daun polohungo (puring), bakohati (ramuan lulur atau bedak yang harum), dan bulowe (tangkai mayang pinang). 


\section{1 | JURNAL ILMU BUDAY}

c. Prosesi injak piring dilakukan dengan cara diiringi oleh orang tua sang anak. Ibu membantu anak menginjakkan piring pertama hingga ketujuh, sedangkan ayah memayungi setiap langkah sang anak. Prosesi injak piring dilakukan tiga kali berturut-turut.

d. Kemudian paye yilulo (beras lima warna) ditaburkan ke seluruh ruangan rumah.

e. Setelah prosesi selesai, maka berakhir pula upacara adat Mongubingo kemudian dilanjutkan dengan do'a dan santap bersama.

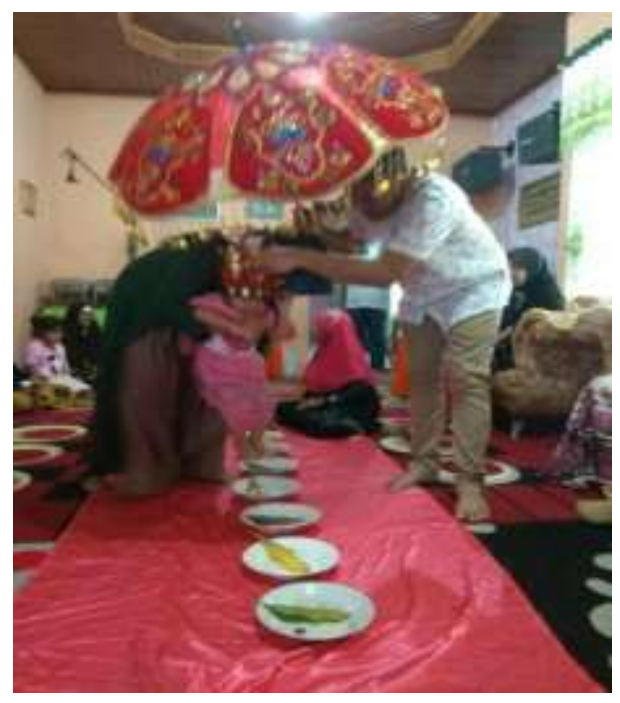

Gambar 3. Prosesi mopohuta'a to pinggae

\section{Makna Filosofis dalam Upacara Adat Mongubingo}

Dalam tinjauan makna filosofis, satu bahan penting menuju makna filosofis adalah simbol. Simbol memiliki arti penting dalam kebudayaan karena simbol merupakan representasi dari dunia dalam kehidupan sehari-hari. Orang-orang sangat memerlukan dan membutuhkan simbol untuk mengungkap dan menangkap tentang sesuatu hal. Kebudayaan sebagai bentuk nyata pemikiran filsafat menggunakan simbol dalam pengungkapannya, sebab simbol mengandung makna atau maksud tertentu yang terjalin dalam hubungan antara simbol dengan objeknya. Dalam sejarah pemikiran, simbol mempunyai dua arti yaitu pertama, sebagai pemikiran dan praktek keagamaan. Simbol dianggap sebagai gambaran yang terlihat dari realitas transenden. Kedua, sistem pemikiran logis dan ilmiah, simbol dipakai dalam arti tanda abstrak (Agustianto, 2011). Menurut Zoest (1993) simbol atau tanda merupakan unsur penting dalam berperilaku dan berkomunikasi agar berbagai makna agar pesan dapat dimengerti (Waode Fian Adilia dan Ikhwan M. Said, 2019).

Makna simbolik dalam tinjauan filosofis upacara adat dapat ditemukan dengan penggunaan simbol-simbol pada prosesi Mongubingo. Simbol-simbol berperan sebagai media komunikasi antara sesama manusia, dan juga menjadi penghubung antara dunia empirik dengan dunia yang non-empirik. Terbentuknya simbol dalam upacara adat Mongubingo tidak dapat dilepaskan pada pendasaran konsep hidup dan nilai etis yang dipegang teguh oleh masyarakat.

Makna filosofis upacara adat Mongubingo pertama yakni dalam prosesi momonto dan lihu lo limu. Sebelum anak memasuki prosesi khitan, anak perempuan terlebih dahulu menjalani prosesi pemberian tanda sunci (momonto) dengan dengan memberikan alawahu tulihi (kunyit yang dicampur kapur) di dahi, leher, di bawah tenggorokan, di bahu, dan pada lekukan tangan dan kaki sang anak perempuan oleh orang tua. Makna tanda yang diberikan di dahi menunjukkan suatu pernyataan untuk tidak menyembah selain kepada Allah. Tanda di leher bermakna agar anak tidak memasukkan makanan yang haram di dalam tubuhnya. Tanda di tenggorokan merupakan representasi bahwa setiap nafas manusia harus senantiasa diiringi dengan dzikir. Tanda di bahu merupakan suatu bentuk kesiapan manusia untuk memikul tanggung jawab atas amanah yang diberikan oleh Allah. Sedangkan tanda yang diberikan pada lekukan tangan dan kaki bermakna agar 


\section{2 | JURNAL ILMU BUDAY}

senantiasa melakukan perbuatan yang sesuai dengan ajaran dan menghindarkan dari perbuatan tercela (Djibu, 2016).

Pada prosesi lihu lo limu (pengkhitanan), anak perempuan dikhitan oleh bidan kampung (hulango); bagi masyarakat Gorontalo, hulango memiliki otoritas terkait adat kelahiran hingga kematian. Prosesi khitan dilakukan di dalam ruangan yang gelap dengan mengambil sedikit selaput tipis yang ada di alat vital anak perempuan, dalam prosesi khitan digunakan tohetutu (lampu tradisional) sebagai penerang prosesi khitan dan saat prosesi khitan hulango menutupi dirinya dan sang anak dengan alumbu (kain putih). Tohetutu bermakna sebagai penerang kehidupan, sedangkan kain putih sebagai lambang kesucian. Secara garis besar prosesi khitan bermakna bahwasannya seorang perempuan perlu dibatasi hasratnya terhadap lawan jenis, karena pada dasarnya perempuan perlu dibatasi agar bisa mengontrol dirinya untuk menjadi perempuan yang sesuai dengan adat dan budaya Gorontalo, serta agama Islam.

Prosesi mo polihu lo limu (mandi lemon) dilakukan di suatu tempat sekitar rumah penyelenggara yang telah dihiasi oleh berbagai macam benda, seperti pisang gapi, batang tebu, tunas kelapa, mayang pinang, daun puring. Setiap benda-benda yang digunakan mengandung makna filosofis. Pisang gapi dan tebu memiliki rasa yang manis sehingga anak yang diadat diharapkan menjadi anak yang manis di mata orang lain, tidak membeda-bedakan antar manusia, dan serta memiliki hati yang manis. Tunas kelapa merepresentasikan bagaimana pohon kelapa dapat tumbuh secara kuat, oleh karena itu diharapkan sang anak menjadi manusia yang kuat, bermanfaat, dan memiliki rasa cinta yang tumbuh dan bertahan dengan kuat. Mayang pinang pada dasarnya berbau harum, hal ini bermakna suatu harapan agar kelak menjadi manusia yang harum baik secara fisik maupun batin. Sedangkan daun polohungo bermakna sebagai tolak balak, karena bagi masyarakat Gorontalo tanaman poluhungo ditanam di pekarangan rumah dan dipercaya dapat menghindarkan halhal yang buruk bagi penghuninya. Kemudian sang anak didudukkan di pangkuan ibu di atas kukuran kelapa (dudungata) dan menghadap ke timur. Kukuran kelapa mewakili salah satu perangkat dapur bagi masyarakat Gorontalo, anak perempuan diharapkan dapat memenuhi kodratnya yaitu mengerjakan tugas-tugas rumah tangga bagi keluarga. Upacara mandi lemon diselenggarakan di pagi hari dan dengan menghadap ke arah Timur. Hal ini dikarenakan arah Timur merupakan arah terbitnya matahari yang merupakan sebuah harapan agar anak selalu dalam keadaan segar seperti halnya matahari terbit di pagi hari. Prosesi berikutnya yaitu siraman menggunakan air harum yang sudah diramu. Air yang diharumkan tersebut yang terdiri atas kulit lemon yang dihaluskan, bunga melati, daun onumo (daun harum), umonu (ramuan yang sudah ditumbuk halus), tujuh macam daun polohungo (puring) yang dihaluskan lalu dan diiris-iris, dan tujuh buah limututu (lemon Sowanggi) yang sudah diiris-iris. Pemilihan angka tujuh dipilih karena bentuk penggambaran watak yang ada pada setiap anak perempuan di Gorontalo yaitu: 1) nakal (nene'alo) 2) tidak jujur (wetetelo) 3) berbicara yang menyenangkan orang lain (kureketolo) 4) membangkang (pa'ingolo) 5) terlalu gesit (kekengolo) 6) berbicara tanpa tujuan (bulabulolo) 7) kasar (hutatingolol bangganga) (Lamusu, 2016). Sedangkan makna tujuh buah perian bambu kuning yaitu untuk mendapatkan kemuliaan, perlu mensucikan diri dari dosa lahir yang dilakukan oleh tujuh anggota badan, yaitu mulut, mata, telinga, hidung, kaki, tangan, dan kemaluan (Sinaga, 2005). Makna prosesi siraman adalah mengharumkan dan membersihkan diri anak perempuan 


\section{3 | JURNAL ILMU BUDAY}

sebelum mencapai usia yang lebih dewasa. Prosesi dilanjutkan dengan tepuk pinang. Masyarakat Gorontalo percaya apabila dalam prosesi tersebut pinang mudah pecah, maka sang anak akan mudah dalam menempuh hidupnya, sedangkan apaila tidak mudah pecah, maka sang anak dipercaya akan banyak menghadapi rintangan dalam hidupnya. Selanjutnya prosesi pecah telur, penggunaan telur merupakan suatu harapan agar anak hatinya bulat seperti telur. Dalam prosesi pecah telur, apabila dalam prosesi kuning telur pecah, dipercaya maka masa depan sang anak buruk dan tidak dapat menjaga kehormatannya karena tidak dapat membedakan antara kebaikan dan keburukan, apabila tidak pecah maka kelak masa depan sang anak akan baik dan dapat menjaga kehormatannya.

Prosesi yang terakhir adalah mopohuta'a to pinggae (injak piring). Dalam prosesi ini terdapat tujuh buah piring yang telah diisi berbagai macam benda, yaitu segeggam tanah dan tanaman rumput, biji jagung, padi, uang koin, daun puring, bakohati, dan tangkai mayang pinang. Piring pertama, berisi tanah dan tumbuhan rumput bermakna kehidupan di bumi yang dilambangkan dengan tanah, perlu memperkuat pendirian, keimanan, dan ketakwaan yang dilambangkan dengan tumbuhan rumput. Piring kedua yang berisi jangung bermakna sang anak wajib mempertahankan kesucian dan kehormatan dirinya. Piring ketiga berisi padi bermakna kerendahan hati yang dilambangkan dengan buah padi yang semakin berisi maka semakin menunduk. Piring keempat berisi uang koin bermakna rejeki yang halal. Piring kelima berisi daun puring bermakna adat, yaitu menghindarkan diri dari perbuatan yang memalukan diri sendiri dan keluarga. Piring keenam berisi bakohati bermakna penataan diri anak. Piring ketujuh berisi tangkai mayang pinang bermakna keharuman nama pribadi dan keluarga perlu dijaga. Injak piring dilakukan dengan bantuan sang ibu sedangkan sang ayah memayungi perjalanan menginjak piring. Prosesi injak tujuh piring memiliki makna bahwa sang anak harus berjuang untuk menghadapi berbagai macam bentuk jalan kehidupan, peran seorang ibu adalah membimbing anak sedangkan ayah melindungi. Setelah injak piring, kemudian beras lima warna (pale yilulo) ditabur ke seluruh ruangan rumah dengan maksud agar tidak memperoleh gangguan dari makhluk halus, lima warna menggambarkan lima aliran yang ada dalam tubuh manusia. Merah merupakan gambaran atas darah merah yang mengalir pada tubutuh manusia, putih simbolisasi atas darah putih, ungu merepresentasikan warna daging manusia, hijau simbol dari urat yang ada di dalam diri manusia, sedangkan warna kuning adalah simbol dari sumsum manusia (Lamusu, 2016).

\section{Nilai Religi}

Nilai religius merupakan nilai yang bersumber dari kenyataan yang bersifat mutlak sehingga nilai ini erat kaitannya dengan Tuhan. Kepercayaan manusia akan nilai keagungan, kesucian, dan keadilan Tuhan yang bersifat absolut. Tuhansebagai Yang Kudus dan nilainya yang disebut sebagai nilai kudus menjelma dalam nilai religius yang kemudian terkadung dalam aktivitas-aktivitas manusia. Nilai religius berkaitan dengan bagaimana manusia bersikap dan bertindak berdasarkan dorongan kepercayaan diri kepada Sang Pencipta. Nilai religius tidak hanya terikat kepada satu pedoman atau ajaran agama, melainkan berkaitan dengan sistem kepercayaan terhadap eksistensi Tuhan, sebab itu kemudian nilai religius masih merupakan nilai yang luas cakupannya. Namun, dalam hal ini, masyarakat Gorontalo mendasarkan nilai religius pada ajaran agama Islam untuk menentukan kaidah adat .

Masyarakat Gorontalo menjalankan syariat agama Islam salah satunya melalui 


\section{4 | JURNAL ILMU BUDAY}

adat yang berlaku, yaitu adat yang berlandaskan syariat agama Islam. Hal tersebut tercermin pada falsafah masyarakat suku Gorontalo "Adat bersendikan syara', syara' bersendikan kitabullah" (adat berlandaskan syariat, syariat berlandaskan kitabullah). Sebab itulah, kemudian melalui adat, pemahaman religius masyarakat Gorontalo berpusat. Ketika masyarakat Gorontalo memperoleh pengetahuan mengenai nilai-nilai religius melalui pengetahuan yang telah ditanamkan dalam sistem adat, mereka akan lebih mudah menemukan dimensi praktis dalam sistem religi. Melalui adat yang berlandaskan nilai-nilai religius, masyarakat Gorontalo memberikan status adat sebagai hal yang sakral, dan memiliki nilai kesucian.

Bagi masyarakat Gorontalo, upacara adat Mongubingo merupakan adat yang menjadi permulaan anak perempuan memasuki agama Islam. Sang anak mulai diikatkan perjanjian pada ajaran agama Islam melalui upacara adat Mongubingo. Hal tersebut nampak dalam makna filosofis prosesi momonto (pemberian gelar suci kepada anak perempuan) yaitu untuk tidak menyembah selain kepada Allah, tidak memasukkan makanan yang haram di dalam tubuhnya, nafas yang senantiasa diiringi dengan dzikir, kesiapan memikul tanggung jawab atas amanah yang diberikan oleh Allah, serta senantiasa melakukan perbuatan yang sesuai dengan ajaran dan menghindarkan dari perbuatan tercela. Dalam artian yang lebih ringkas, bahwa bayi perempuan secara simbolik mulai diikatkan dengan ajaran dasar agama Islam melalui upacara adat Mongubingo.

Dorongan religius dalam penyelenggaraan upacara adat Mongubingo merupakan dorongan terkuat yang dipegang teguh oleh masyarakat Gorontalo. Melalui dorongan religius, upacara adat Mongubingo berstatus sebagai sebuah kewajiban yang tidak bisa ditawar dengan apapun bagi masyarakat
Gorontalo. Dari hasil wawancara yang dilakukan terhadap 15 orang tua yang pernah menyelenggarakan upacara adat Mongubingo, sebanyak $93 \%$ menjawab bahwa upacara adat merupakan syariat agama Islam yang wajib dilakukan, sedangkan sisanya menjawab hanya bagian dari adat masyarakat suku Gorontalo terlepas dari syariat agama Islam. Dari data tersebut, penyelenggaraan upacara adat Mongubingo dipahami oleh masyarakat suku Gorontalo sebagai sesuatu yang sakral dan kewajiban beragama ketika memiliki anak perempuan. Selain itu, penerimaan upacara adat Mongubingo sebagai bagian syariat Islam juga mempengaruhi pola pikir masyarakat Gorontalo, terutama orang tua senantiasa memiliki kesadaran pribadi untuk menyelenggarakan upacara adat Mongubingo ketika memiliki anak perempuan.

Eksistensi nilai religius dalam adat Mongubingo tersebut merupakan nilai terdasar yang menjadikan tradisi khitan perempuan tetap berlaku secara lestari pada masyarakat suku Gorontalo meskipun banyak mendapatkan kritik dari segi kesehatan, pemberdayaan perempuan, dan perlindungan anak. Namun sesungguhnya masyarakat suku Gorontalo bukanlah masyarakat yang tertutup, melainkan mereka dapat menerima pengaruh dari luar. Pengaruh-pengaruh dari luar yang dating diseleksi dan disesuaikan dengan perangkat adat dan agama yang ada berkat kuatnya pengaruh agama dan adat pada msayarakat Gorontalo. Penyesuaian yang sejak dahulu hingga sekarang adalah penyesuaian yang tidak bertentangan dengan ajaran agama Islam, serta tidak mengucilkan nilai dan makna yang terdapat dalam budaya masyarakat Gorontalo (Sinaga, 2005).

\section{Nilai Etis}

Nilai etis adalah nilai-nilai dan norma-norma yang menjadi pegangan bagi 


\section{5 | JURNAL ILMU BUDAY}

seseorang atau suatu kelompok dalam mengatur tingkah lakunya (Bertens, 2013). Dalam pengertian ini, nilai etis berkaitan dengan bagaimana sebuah masyarakat menetapkan pedoman tindakan berdasarkan kesepakatan moral, sehingga menyebabkan adanya penilaian baik dan buruk. Nilai etis juga dapat diartikan sebagai kualitas tindakan tertentu yang diharapkan oleh manusia.

Posisi Gorontalo sebagai salah satu daerah adat di Indonesia menempatkan berbagai tradisi yang sudah berkembang sebagai kebiasaan masyarakat yang mengandung nilai kebaikan. Sistem adat yang dibangun didasarkan pada pemahaman agar manusia memiliki kualitas tingah laku atau adab yang baik. Nilai etis dalam penyelenggaraan adat yang kuat merupakan sebuah kualitas yang diharapkan agar manusia dapat memperoleh penerimaan dari komunitas masyarakat. Dengan diberlakukannya adat secara turun-temurun, masyarakat suku Gorontalo akan memiliki rasa kepemilikan (sense of belonging) terhadap adat, sehingga akan tetap melestarikannya dari waktu ke waktu.

Upacara adat Mongubingo adalah tradisi siklus kehidupan yang tidak dapat dilepaskan dari kehidupan seorang perempuan suku Gorontalo, pasalnya masyarakat suku Gorontalo memiliki adat yang mengatur awal kehidupan hingga akhir kehidupan manusia, yang setiap bagiannya memiliki makna filosofis yang berbeda. Upacara adat Mongubingo yang diperuntukkan bagi bayi perempuan usia satu hingga tiga tahun tentu dibedakan dengan upacara bagi bayi suku Gorontalo seperti kelahiran atau aqiqah.

Dalam adat Mongubingo, anak perempuan mulai diajarkan bagaimana ia dapat tumbuh kembang menjadi perempuan yang beradab sesuai dengan konsep suku Gorontalo. Hal ini tercermin dari makna filosofis yang terkandung dari masin-masing tahapan prosesi adat Mongubingo. Dari prosesi lihu lo limu (prosesi khitan) menyiratkan nilai kebaikan agar sang anak kelak mampu menjaga kemaluannya, prosesi momonto (pemberian tanda suci) mengharapkan agar sang anak mampu mengamalkan ajaran agama Islam, prosesi lihu lo limu (mandi lemon) mengharapkan kelak sang anak dapat menjadi pribadi yang bermanfaat bagi keluarga dan orang lain. Penyelenggaraan upacara adat Mongubingo bagi masyarakat Gorontalo adalah sesuatu yang wajib dilakukan. Kewajiban tersebut tidak hanya dalam prosesi khitan bagi anak perempuan sebagai inti dari tradisi, melainkan secara keseluruhan dari prosesi khitan hingga injak piring. Dari hasil temuan di lapangan, penyelenggaraan upacara adat Mongubingo adalah wajib bagi semua kalangan masyarakat suku Gorontalo yang memiliki anak perempuan, termasuk semua kalangan dalam berbagai kelas ekonomi. Namun biasanya masyarakat dengan tingkat ekonomi rendah, menengah, dan atas memiliki perbedaan dalam segi perayaan, dimana masyarakat dengan tingkat ekonomi rendah dan menengah biasanya mengadakan upacara adat secara sederhana dengan hanya melibatkan sanak saudara atau tetangga dan pemangku adat setempat, sedangkan apabila penyelenggara dalam kategori ekonomi atas biasanya mereka mengundang pejabat daerah dan beberapa baate (pemangku adat daerah).

Kendala secara ekonomi dalam penyelenggaraan upacara adat Mongubingo tidak menjadi penghambat bagi masyarakat suku Gorontalo untuk tetap melakukan adat yang dianggap sebagai kewajiban ini, bahkan apabila ada sebuah keluarga tidak mampu secara total menyelenggarakan upacara adat Mongubingo, biasanya kerabat dekat atau tetangga secara gotongroyong membantu proses penyelenggaraan adat tersebut.

Konsep kebaikan dalam upacara adat Mongubingo tidak hanya dipegang oleh masyarakat secara individu, melainkan juga menjadi tanggung jawab 
sosial masyarakat setempat untuk senantiasa menyelenggarakan adat yang berlaku dalam lingkup sosial suku Gorontalo. Gotong-royong adalah sebuah konsep nilai kebaikan agar masyarakat suku Gorontalo hidup berdampingan antar sesama. Dengan demikian, pelestarian upacara adat Mongubingo sesungguhnya tidak hanya berlaku secara personal bagi setiap suku Gorontalo, melainkan sudah menjadi tanggung jawab bersama sebagai kesepakatan hidup bermasyarakat. Masyarakat suku Gorontalo yang tidak melaksanakan adat dimungkinkan mereka kehilangan sosialitas mereka hidup dalam sebuah kesamaan filosofis. Sehingga secara tidak langsung upacara adat Mongubingo dapat bertahan hingga saat ini karena peranan kolektif masyarakat suku Gorontalo itu sendiri.

Masyarakat Gorontalo juga meyakini bahwa upacara adat Mongubingo merupakan cara untuk membentuk karakter dan pola kehidupan, serta tingkah laku anak perempuan. Mereka mendasarkan melalui tradisi Mongubingo, kelak sang anak perempuan terhindar dari tingkah laku yang tidak sesuai dengan adat setempat, terutama agar dapat membatasi diri dengan lawan jenis. Dalam beberapa kajian medis, khitan perempuan akan berpengaruh pada pengurangan hasrat seks pada perempuan. Bagi masyarakat Gorontalo, hal ini bukan hanya dimaknai sebagai reduksi hasrat secara fisiologis saja, melainkan terkandung sebuah konsep nilai etis agar kelak perempuan diharapkan senantiasa mampu membatasi dirinya terhadap lawan jenis, agar perempuan dapat menjaga kehormatannya. Kemudian inilah yang dapat dihubungkan bagaimana konsep upacara adat Mongubingo sebagai nilai agar perempuan Gorontalo mampu mengendalikan tingkah lakunya.

Dapat dikatakan bahwa upacara adat Mongubingo memiliki nilai keutamaan moral serta keluhuran (virtue) untuk membentuk karakter anak sesuai dengan budaya yang dianut dalam tatanan adat Gorontalo. Upacara adat Mongubingo adalah keutamaan bagi bayi perempuan dalam mengendalikan nafsu yang ada sejak dini untuk membentuk perilaku dan tindakan. Hal ini dilakukan melalui pengendalian tingkah lakunya dalam masyarakat seiring perkembangan umur dan kehidupannya sehingga tercapai aspek keluhuran yang diinginkan.

\section{KESIMPULAN}

Upacara adat Mongubingo pada masyarakat suku Gorontalo merupakan upacara khitan pada bayi perempuan berumur 1-3 tahun yang terdiri atas khitan dan diakhiri dengan mandi lemon. Adat Mongubingo ini masih dilestarikan pelaksanaannya pada masyaraat Gorontalo berdasarkan falsafah pelaksaan adat berdasarkan agama. Melalui berbagai simbolisasi dan makna filosofis yang ada dalam upacara adat Mongubingo, masyarakat Gorontalo percaya bahwa tradisi Mongubingo memiliki nilai kebaikan. Nilai kebaikan tersebut bersumber dari nilai religi yang dianut sebagai dasar menjalankan tradisi Mongubingo, nilai ini tidak dapat dilepaskan dari masyarakat Gorontalo karena sejatinya mereka melandaskan kehidupannya berdasarkan falsafah "Aadati hulahula to saraa, Saraa hulahula to kuru'ani" yang berarti adat bersendikan syara', syara' bersendikan kitabullah.

Secara garis besar, nilai filosofis yang terkandung dalam upacara adat Mongubingo adalah sebuah harapan akan masa depan yang baik bagi anak perempuan. Keberadaan nilai-nilai yang terkandung dalam upacara adat Mongubingo merupakan faktor kuat yang menyebabkan tradisi tersebut tetap eksis hingga saat ini. Nilai religi adalah nilai yang mendasari mengapa upacara adat ini masih dilakukan hingga sekarang. Melalui nilai religi, masyarakat Gorontalo memaknai tradisi ini sebagai kewajiban yang harus dijalankan. Sedangkan nilai etis 


\section{7 | JURNAL ILMU BUDAYA}

Volume 8, Nomor 2, 2020

adalah nilai-nilai yang menjadi acuan atau tujuan akhir upacara adat Mongubingo, yaitu pengendalian tingkah laku perempuan yang diharapkan selalu sesuai dengan yang diharapkan oleh masyarakat Gorontalo.

Konsep nilai etis yang dibangun melalui upacara adat Mongubingo merupakan dasar sebagai tujuan akhir kehidupan perempuan di tengah-tengah masyarakat Gorontalo yaitu menjadi perempuan yang dapat mengontrol perilaku dan beradab sesuai dengan adat, budaya, dan agama yang berlaku. Dengan tujuan tersebut, masyarakat Gorontalo meyakini bahwa hal ini akan menghantarkan mereka pada kebahagiaan dunia dan akhirat.

\section{DAFTAR PUSTAKA}

Agustianto. 2011. Makna Simbol dalam Kebudayaan Manusia. Jurnal Ilmu Budaya, Vol. 8., No. 1., 1-8.

Bertens, K. 2013. Etika. Yogyakarta: Kanisius.

Djibu, F. 2014. Makna Dan Nilai Tradisi Mo Polihu Lo Limu Pada Masyarakat Gorontalo. Universitas Negeri Gorontalo, Jurusan Pendidikan Sejarah, Fakultas Ilmu Sosial, Gorontalo.

Hassanudin \& Basri Amin. 2012. Gorontalo Dalam Dinamika Sejarah Masa Kolonial. Yogyakarta: Penerbit Ombak.

Kaelan. 2005. Metode Penelitian Kualitatif Bidang Filsafat. Yogyakarta: Paradigma.

Lamusu, S. A. 2016. Semiotics And Its Application In Pohutu Aadati Lihu Lo Limu Devices In Gorontalo. Humaniora, Vol. 28, Num. 2, 215228.

Nofitasari, D.V., Rosyadi,I., Muslimin, M., Hendrawan, R., Yudistio,K., Sa'adah, Z., Dharmawan, A.S.
2020. Harmonisasi Masyarakat Tengger Dalam Upacara Yadnya Karo. Jurnal Ilmu Budaya. Vol. 8., No. 1, 140-145.

Moleong, L. J. 1991. Metode Penelitian Kualitatif. Bandung: Remaja Rosda.

Sinaga, M. 2005. Upacara Adat Propinsi Gorontalo. Gorontalo: Departemen Kebudayaan Dan Pariwisata.

Soelaeman, M. 1992. Ilmu Budaya Dasar: Suatu Pengantar. Bandung: $\mathrm{Pt}$ Eresco.

Sulthan, S. 2017. Dinamika Khitan Bagi Perempuan Di Kelurahan Bara Baraya, Kecamatan Makassar, Kota Makassar. Makassar: Uin Alauddin Makassar.

Waode Fian Adilia Dan Ikhwan M. Said. 2019. Ritual Posuo 'Pingitan' Pada Masyarakat Suku Buton: Kajian Semiotika. Jurnal Ilmu Budaya, Volume 7, Nomor 2, 273-281. 